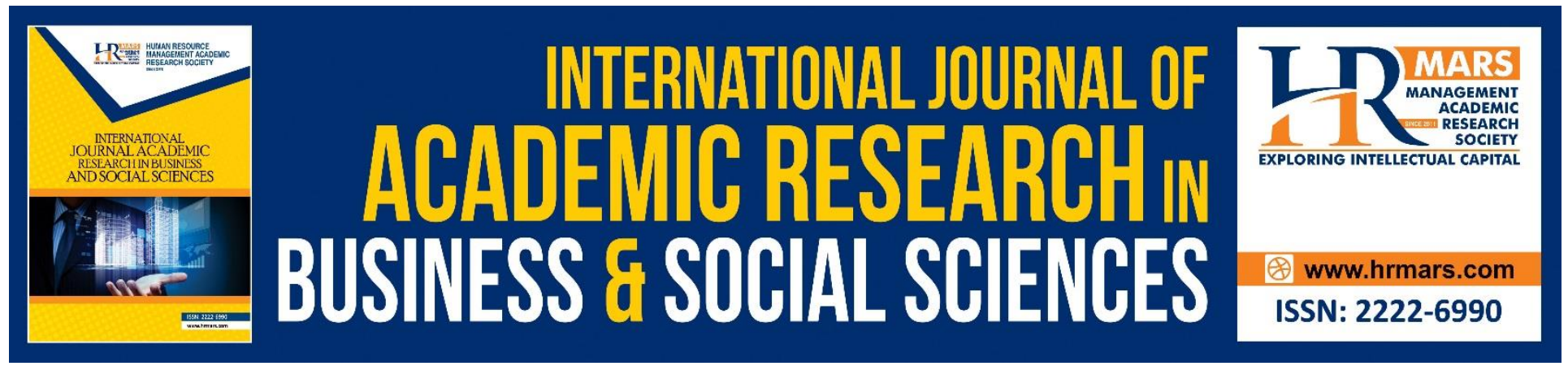

\title{
Importance and Uses of Forest Product Bamboo and Rattan: their Value to Socioeconomics of Local Communities
}

Wan Rafiekal Wan Abdul Rahim \& Roszehan Mohd Idrus

To Link this Article: http://dx.doi.org/10.6007/IJARBSS/v8-i12/5252

DOI: $10.6007 /$ IJARBSS/v8-i12/5252

Received: 16 Nov 2018, Revised: 20 Dec 2018, Accepted: 24 Dec 2018

Published Online: 09 Jan 2019

In-Text Citation: (Rahim \& Idrus, 2018)

To Cite this Article: Rahim, W. R. W. A., \& Idrus, R. M. (2018). Importance and Uses of Forest Product Bamboo and Rattan: their Value to Socioeconomics of Local Communities. International Journal of Academic Research in Business and Social Sciences, 8(12), 1484-1497.

\section{Copyright: (C) 2018 The Author(s)}

Published by Human Resource Management Academic Research Society (www.hrmars.com)

This article is published under the Creative Commons Attribution (CC BY 4.0) license. Anyone may reproduce, distribute, translate and create derivative works of this article (for both commercial and non-commercial purposes), subject to full attribution to the original publication and authors. The full terms of this license may be seen

at: $\underline{\text { http://creativecommons.org/licences/by/4.0/legalcode }}$

Vol. 8, No. 12, 2018, Pg. 1484 - 1497

http://hrmars.com/index.php/pages/detail/IJARBSS

JOURNAL HOMEPAGE

Full Terms \& Conditions of access and use can be found at http://hrmars.com/index.php/pages/detail/publication-ethics 


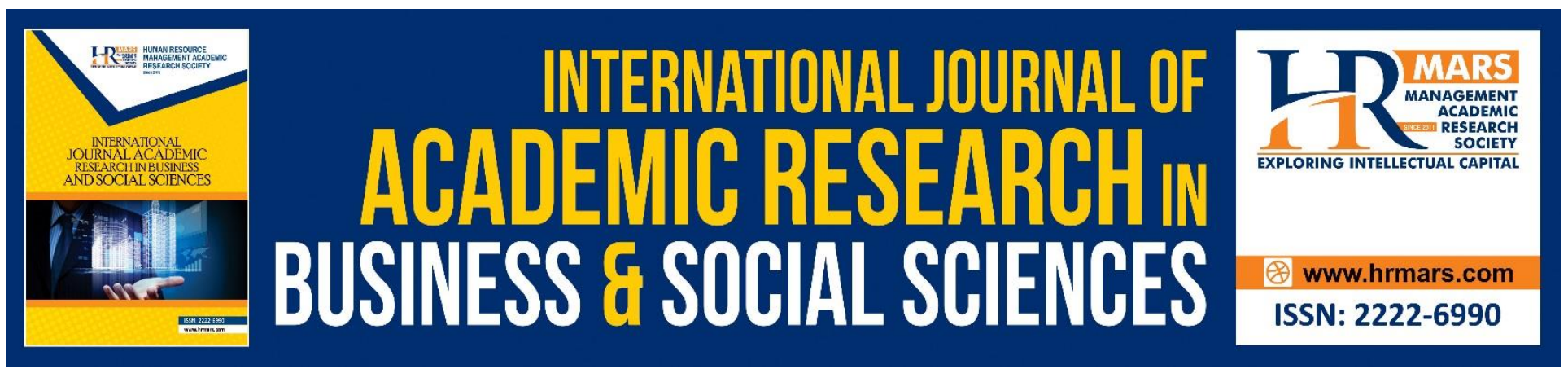

\title{
Importance and Uses of Forest Product Bamboo and Rattan: Their Value to Socioeconomics of Local Communities
}

\author{
Wan Rafiekal Wan Abdul Rahim \& Roszehan Mohd Idrus \\ ${ }^{1}$ School of International Tropical Forestry Universiti Malaysia Sabah
}

\begin{abstract}
The study was conducted to determine the value of non wood forest products to the socioeconomic of local communities in Kelawat Kota Belud Sabah which is to identify the importance and uses of bamboo and rattan in the livehood of villagers also the advantage of using these products. Respondents surveyed were residents of four villages in Kelawat which is Ponopuan Village, Kelawat Village, Sumbilingon Village and Pangi Village. Data was collected by a questionnaire survey and interviews with respondents. From the research, a total of 102 respondents surveyed are involved in the use of bamboo and rattan. $33(32.4 \%)$ of them use bamboo and rattan as a source of their income for socioeconomic while 69 (67.6\%) others used bamboo and rattan for their own consumption. A total of 73 villagers agreed and strongly agreed that bamboo and rattan help in improving their socioeconomy. Bamboo and rattan are mainly used for handicrafts, followed by the manufacturing furniture and house construction, as well as source of food and other uses, for example musical instruments. Percentage of average total income of bamboo and rattan sales with the total income per month was $31.85 \%$ which concluded that bamboo and rattan give an important value to help in improving the socioeconomy of local communities.
\end{abstract}

Keywords: Socioeconomic, Communities, Consumption, Source, Forest Products, Income, Sales

\section{INTRODUCTION}

The forestry sector is one of important sources of socioeconomic development in the country. Socioeconomic can be defined as activities involving communities in the economy including economic and social factors (Johari Baharuddin \& Salleh Md Noor, 2007). It is a study of the relationship between economic activity and social life. The term forest community simply means managing a group of trees by a group of people who have the same purpose (Vermeulen, 2001). Community forestry is defined as the dominance and profitability of local communities gain from local forest resources. These benefits are not only from the production of wood but also have the various benefits from the forest ecosystems, including cultural, spiritual, social, health, ecological, recreational, aesthetic and economic values (Curran \& M'Gonigle, 1999). 
The Borneo community has a long tradition of using and relying on forest resources not only using agricultural land for planting but also collecting forest product. Although today it has shifted to the modern market economy but in the local community it continues to be an integral part of their daily life (Brookfieldet al., 1995). This forest revenue collection activity is critically perceived as a source of livelihood, income generation and cultural practices (Mertz et al., 1999) which is estimated that $80 \%$ of the population in developing countries use forest products for living, consumption and income (Johari et al., 1998).

FAO defines non-timber forest product as a genuine biological product other than timber derived from forests for human needs. It is one of the forest resources that has a close association with the surrounding of forest communities (FAO, 1999). Economically, non-timber forest products have a high economic value and have the potential to increase people's income and welfare. The most important source of non-timber forest products in Malaysia and other Southeast Asian countries are bamboo and rattan. It is a non-timber forest product that give a main source for communities in develop their socioeconomic because the bamboo and rattan functions and interests are used in construction, furniture, handicraft and so on.

\section{Non-Timber Forest Products Bamboo and Rattan}

Forest area has a variety of raw materials that can be used by humans. Through the forest, humans can obtain forest products such as timber, bamboo, rattan and so on that can help to the economic development of a country. This is because the forest products have a commercial value in the present and the demand for these forest products is high either locally or overseas. Center for International Forestry Research (CIFOR), 2011 estimates that families living in and around the forest earn an average of one fifth of their income from forest-based sources. In many countries, non-timber forest products largely contribute to the economy and local livehood which also among the most important exports. According to FAO statistics, (2007) it is estimated that the value of non-timber forest products to US is $\$ 18.5$ billion in 2005 . Through some of the studies conducted, it is undeniable that the most important non-timber forest resource in Malaysia as well as some Southeast Asian countries is bamboo and rattan.

Bamboo originates from the grass family (Graminea) and is classified in the genus of Bambusae. It is the largest grass in the world and can reach a height of $40 \mathrm{~m}$ with a stem of $30 \mathrm{~cm}$. There are 75 genus and 1250 species around the world. The distribution of bamboo in the world is widespread and its original growth habitat is found in all continents except Europe. In the past, bamboo was considered a weed in the forest, but it is now known as a plant with many uses (Maxim et al., 2005).

The range of bamboo utilization in recent years has received more general attention. The introduction of Southeast Asian countries has shown that it has proven to be a sustainable and valuable natural resource (Dannenmann, 2007). It plays an important role in the socio-economic status of the rural population (Prasad, 1990). Bamboo, which was previously regarded as 'The Poor Man's Timber', is unaware of the commercial value now known as 'The Green Gold' which plays an 
important role in society since its time and today it contributes to the need for more than a billion people worldwide (Salam, 2008).

Bamboo has been used traditionally as fuel, food, fence shelters and various other purposes such as making vegetable baskets, stalks, pens or animal cages. Bamboo is also used as a light barrier decoration and 'bonsai'. In modern times today, bamboo is also used as a raw material for pulp and paper industry raw materials, construction materials and engineering, product panels, and so on. The furniture industry and bamboo handicrafts have been thrived nowadays. Bamboo fibers with average length of $3.45 \mathrm{~mm}$ can produce paper like coniferous trees in moderate-tempered countries. In Malaysia there are two types of bamboo used to produce pulp and paper namely Dendrocalamus giganteus and Dendrocalamus asper (Abd Latif et al, 1998).

Bamboo also has excellent nutritional value in health care such as vitamins, amino acids, flavines, phenolic acids, polysaccharides and extracts that can be extracted from bamboo. It has been widely accepted especially in East Asian countries such as China, Korea, and Japan due to their value in healthcare. Some of the materials extracted from the bamboo can be used in the fresh taste for storage or preservation of foodstuffs. Bamboo contains $2 \%$ to $5 \%$ flavine and phenolic compounds that have the power to remove subnitrification and fat in the blood (Paglione, 2003).

The use of bamboo has long been associated with local communities in Malaysia (Wong, 1988). Bamboo is used by all races in Malaysia for the same purpose to meet their needs. In Malaysia the local bamboo industry can be classified into the production of traditional and modern products. Traditional bamboo use includes shelters, food sources, cooking utensils, musical instruments, hunting guns, handicrafts and furniture. For modern use, bamboo continues to be commercially developed for products such as sunshades, tongs, mats, paper, veneer and laminated furniture (Wahab, 2006). However, the production of bamboo products is associated with factors such as species, age and length of stems obtained from the area (Wahab, 2006).

Bamboo is used in the construction of houses as roofs and walls, as well as reinforcing concrete in road construction. It has a variety of uses as a diet for nutrition and from toys to aircraft production (Salam, 2008). Bamboo is the preferred choice because it has a wide range of uses, strength and easy to handle in the manufacturing sector. The use of bamboo in ordinary housing is used in Asia, South America and Africa. In places such as Ecuador and Costa Rica, bamboo technology has been extended to research because bamboo has a low price, safe, comfortable and durable (Wahab, 2006).

Handicraft is one of the usual bamboo uses for traditional societies in Malaysia. Handicrafts are considered as the traditional artistic and souvenir objects of a country. Bamboo local crafts available in Malaysia in items such as cups, pots, caps, baskets, mats, fans and containers (Wahab, 2006). In addition to handicrafts, bamboo is also popular in the production of musical 
instruments especially by local communities in Sabah and Sarawak (Wong, 1988). Usually only mature and thin bamboo is chosen for the production of musical instruments for example bamboo sexaphone and flute made from the tip of the bamboo stems (Wahab, 2006).

Rattan comes from the Palmae family and is classified in the largest group of parafamily calamoidea. Rattan has a common characteristic of having a thorn and climbing but there are also types of rattan that do not climb. Rattan is derived from the Malay word "rattan", local name for palm climbing. It is a thorny palm found in tropical and subtropical forests and rattan resources for advanced rattan industries, now valued at about US $\$ 6.5$ billion a year (ITTO, 1997). This rattan distribution only grows naturally in Asia and West Africa. Most of the rattan that entered the world trade came from Southeast Asia. It was collected, in general, from the wild population, although many recent efforts have focused on the future provision of raw rattan from the cultivated resources (Dransfield \& Manokaran 1998).

In the Malaysian peninsula, rattan can be found at various altitudes from the sea level to the summit of the $3000 \mathrm{~m}$ mountain. There are 13 genus of rattan in the world: Calamus, Daemonorops, Karthalsia, Plectocomia, Plectocomiopsis, Myrialepis, Ceratolobus, Calospatha, Pogonotium, Retispatha, Laccosperma, Eremospatha, and Onecocalamus. Nearly 600 species of rattan are produced from 13 genus. In Peninsular Malaysia only 20 species have been identified for their use and have commercial value. Among them are manau rattan (calamus manau) matang rattan or also known as dok rattan (C. ornatus), manau tikus rattan (C. tumidus), semambu rattan (C. scipionum), dahan rattan (Karthalsia sp) and saga rattan (C caesius). All the species used in the industry are from the genus Calamus with about 60 species all which is estimated that only $20 \%$ of the total species of rattan have commercial value (Dransfield \& Manokaran, 1993).

Rattan is widely used in various uses by the local community and plays an important role in the livelihood strategy of rural people (Sunderland, 2000). Rattan contributes to the economy through the processing of furniture and handicrafts. Among the furniture produced are chairs, tables, beds, and kitchen utensils. The type of rugs rattan are usually used for weaving mats or lining. Rattan stems are very versatile and flexible, unlike bamboo and hardwoods that will crack and will be destroyed when bending, perfect rattan will take shape and curved when the elements of heat and vapor are used. Rattan trunks are very strong and are especially valuable to the furniture and handicraft industries. Countries in Southeast Asia are estimated to export rattan worth about US \$60 million a year. This does not include the amount of ready-made furniture such as furniture, estimated at US $\$$ 4 billion a year, making it the second most important product after wood and timber (Murtedza, 1998).

\section{Socio-Economics and Market of Bamboo and Rattan Forest Products}

Socioeconomic activities can be defined as activities involving people in the economy including economic and social factors (Johari baharuddin \& Salleh Md Noor, 2007). According to the Dewan Bahasa dan Pustaka (2005) dictionary, the fourth edition, socioeconomic is related to, involving elements or social and economic factors. The main purpose of socioeconomic activity is to meet the 
current needs of society as a source of income. Basically, most socio-economic activities of local communities have an impact on the ecosystem. In the last century, forests were largely valued for the commercial value of timber than non-timber forest products which were not regarded as important economic sources (Kigomo, 2007). In the 1900s when large areas of tropical forest were wooded for local use and export, so many non-timber products were removed and destroyed. However, in the 21st century, there has been growing awareness that non-wood forest products are not only important to the ecosystem but also have invaluable functions to the community. Non-wood forest products such as bamboo and rattan certified can generate foreign exchange and are increasingly regarded as valuable commodities around the world. The perceptions and assessments of these products have changed due to the eradication of forests and the decline in wood resources (Kigomo, 2007)

Non-timber forest products have low value products compared to timber which makes them less attractive to larger forest sector companies. Hence, it usually involves a low cost of market entry which make these non-timber and rattan products are monopolized by small-scale enterprises. Nontimber forest products are linked to poverty eradication in increasing community income through the Center For International Forestry Research (CIFOR) study on demand, supply and market characteristics (Scherr et al., 2004).

There are several factors that affect socio-economic impact on forest products such as age, education, size and household income as well as knowledge of the uses of the forest products (Lacuna-Richman, 2007). Although non-timber forest products were promoted in rural land as an approach to socioeconomic development, it was found that the commercialization of non-timber forest products was unsuccessful. There were several studies conducted in the interior of Mexico to analyze factors affecting the commercialization of non-timber forest products. Among them are the improvement of social justice, community organizations and the culture of the local community including economic status. In addition, factors affecting the process of commercialization of nontimber forest products are production, collection, processing, storage, market and sales. And overall the factors that determine the successful level of commercialization of non-timber forest products are market and sales (Marshall et al., 2003).

Among the problems faced by rural producers on the commercialization of bamboo and rattan forest products is the lack of marketing information. Producers often lack information about their product prices in the local market or input to processing a desired product demand in the market, the amount of competition and the quality of the desired product. Then it is also caused by the low source of raw materials which is a result of small range production often have not enough land and stocks growing. Lack of transportation and storage facilities can cause manufacturers to lose $25-50 \%$ of the harvest. In rural land, high transportation costs and less infrastructure such as roads and public transport services reduce the ability of manufacturers to compete in the market. In addition, it is also due to the lack of processing processes or the worries of high production costs. Finally, due to unfavorable policies such as export control and prices that could create high economic barriers for producers (Pswarayi-Riddihough and Jones, 1995; FAO 1987). 
INTERNATIONAL JOURNAL OF ACADEMIC RESEARCH IN BUSINESS AND SOCIAL SCIENCES Vol. 8, No. 12, Dec, 2018, E-ISSN: 2222-6990 @ 2018 HRMARS

\section{METHODOLOGY}

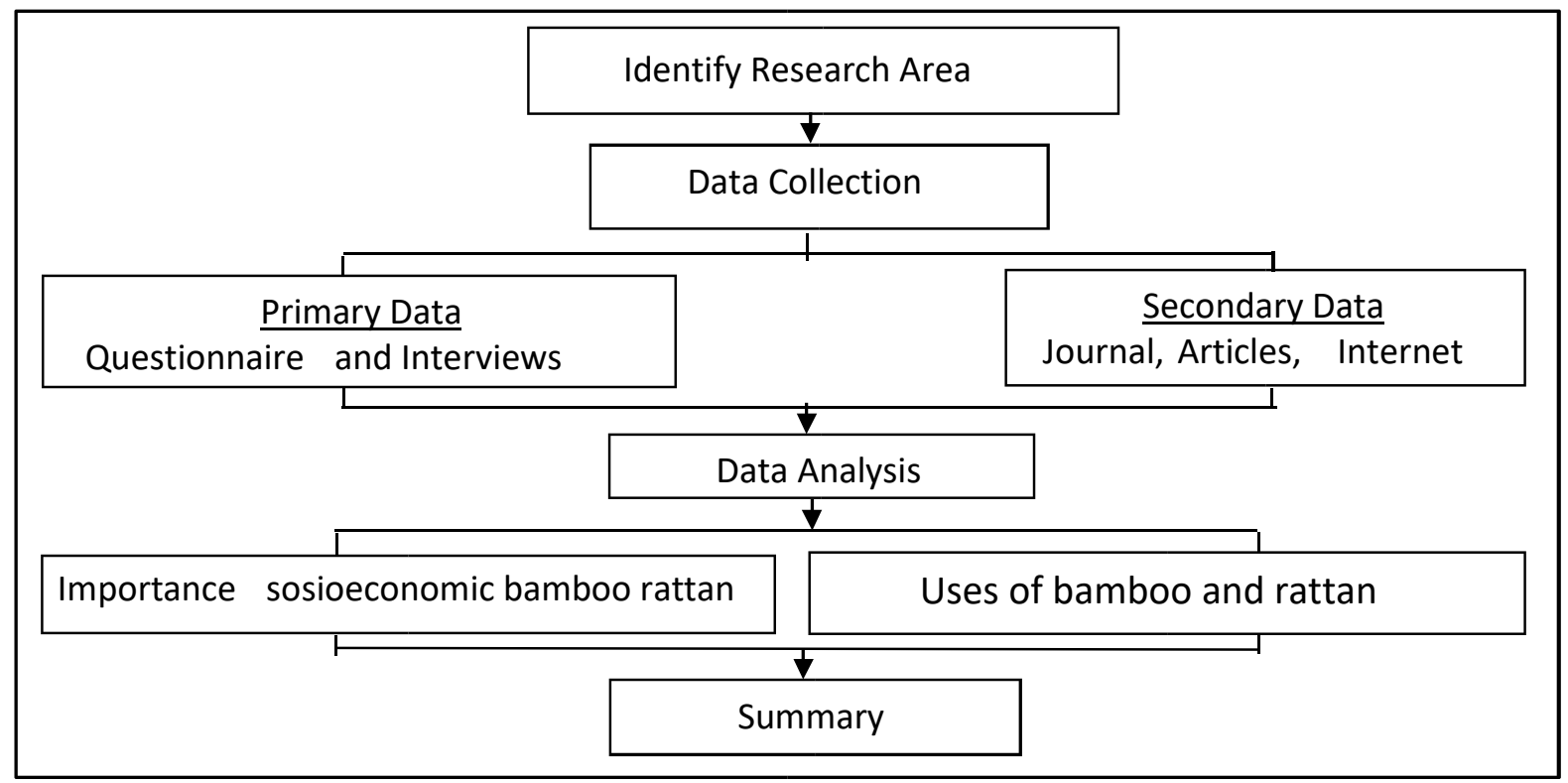

\section{Research Area}

Kota Belud is a town located in the west coast of Central Sulawesi, East Malaysia on the island of Borneo. Kota Belud is along the main road connecting Kota Kinabalu and Kudat. Currently, Kota Belud has 171 villages in which approximately 93,100 people live. The racial according to the majority is Dusun, Bajau, Irranun, Chinese and others where the majority of the races in this district are Muslims. Kelawat is a mukim consisting of the Dusun tribe community located in the hillside along Tamparuli Road. The study area is 4 villages namely Kg. Ponopuan, Kg. Sumbilingon, Kg. Kelawat and Kg. Pangi located in the Kelawat of Kota Belud district. Ponopuan Village is a village located within the Kelawat forest reserve and is set before the reserve forest is gazetted. In 1992, community forestry projects were known as 'joint forest management' between local communities and the Forestry Department were starter. Bamboo climbing is famous especially in the area used as a shifting plant. Most forest reserves are planted with rubber trees and fruits. The villagers living here mostly rubber tappers and planting hill rice.

\section{Data Collection and Analysis}

This study involved two types of data collection, primary data and secondary data. The primary data were collected through a questionnaire involving 102 respondents among the villagers and the sampling method used is "purposive sampling", a purpose sampling that was used to target certain groups who only used the results non-wood forests of bamboo and rattan. In addition, the sampling size used is $60 \%$ of the number of houses for each village. Salkind (1997) suggests that if it is in a survey post or questionnaire, it is necessary to increase the sample size to $40 \%-60 \%$ of the population to avoid missing data and the respondents who do not cooperate. The survey form used is divided into two types namely open and also closed question. The difference between open ended questions 
and closed questions is at in open question, respondents are given the opportunity to answer the question prepared by selecting their own answers but in closed questions, repondents must answer the question by selecting the answer provided in the survey form. Generally the section in this form touches information about the study area, socio-demographic information such as age, race, income, and employment and also the level of study, to what extent they are depending on the product of bamboo and rattan forest as an economic source as well the use of bamboo and rattan in their lives.

Secondary data is collected through journal readings, articles from various reading materials and specific parties as well as the internet. Secondary data collection process was done by reviewing the online data and material by accessing website and published documents. The raw data obtained through the interview was reinterpreted and the data from the questionnaire were recorded and included in the computer evaluation system, which was analyzed carefully using the Statistical Package for Social Science (SPSS) software. SPSS is a computer package used to analyze problems using statistical methods in more details.

\section{RESULTS AND DISCUSSIONS}

\section{The Importance of Bamboo and Rattan Results to Socio-Economics}

The study was carried out by questioning 102 respondents, namely the residents of four villages regarding the importance of bamboo and rattan in assisting their socioeconomics. Based on the results of the study, the majority of respondents agreed and strongly agreed that the results of bamboo and rattan helped to improve socioeconomics with 53 (52\%) and 20 (19.6\%) respondents respectively. A total of $17(16.7 \%)$ respondents stated that they were moderately agree and 11 $(10.8 \%)$ were disagree and one (1.0\%) did not agree at all that bamboo and rattan products could help improve socioeconomics. This suggests that respondents, residents of all four villages, agreed that bamboo and rattan products were important in helping to improve their socio-economic status.

Bamboo and rattan is a non-timber forest product that has many uses and benefits many people. Of the 102 respondents, 33 people (32.4\%) use bamboo and rattan as their source of income, while 69 $(67.6 \%)$ respondents use bamboo and rattan products for their own use. This shows that besides providing employment and income sources, bamboo and rattan products also benefit villagers for their own use as food sources, furniture manufacturing, handicrafts such as baskets, hoods and are used in the construction of their house.

A total of $42(41.2 \%)$ respondents from all surveyed respondents agreed that the advantages of using bamboo and rattan were because they were readily available. Based on the area of research the surveys conducted, there are bamboo and rattan growing in abundance in the surrounding areas of the village and forest areas. Therefore, villagers can easily collect bamboo and rattan for their own use and also as a source of income. On the other hand, 30 people (29.4\%) respondents choose the advantages of using bamboo and rattan this is due to the cheap price. For example, in home and furniture manufacturing, bamboo and rattan are cheaper than other materials such as wood, iron and concrete. In addition to that, other respondents chose they are easily formed and more durable as the advantages of using bamboo and rattan products which each were $16(15.7 \%)$ and $14(13.7 \%)$ 
respectively. Owing to these advantages, today's use of bamboo and rattan is more focused on commercial value for producing attractive handicraft and furniture items. In the rattan industry, usually rattan trunks are classified based on the appearance, flexibility, durability and stem sizes (National Export Development Agency, 1992).

Based on the study, nearly half of the total respondents, 49 (48\%), were involved in collecting bamboo and rattan activities while $53 \%$ (52\%) of the respondents never involve in collecting bamboo and rattan. It still shows that the involvement of respondents in collecting this non wood forest product is still often done because it has become a habit and as a tradition of heredity practiced to this day. There are various factors that prevent in the collection of bamboo and rattan. Of the 53 respondents who collected bamboo and rattan, 22 (21.6\%) respondents chose weather problems such as rainy days as the most important factor in preventing the collection of bamboo and rattan products followed by health problems with a total of 20 (19.6\%) respondents. In addition, 6 (5.9\%) respondents chose the age factor and the rest were caused by environmental problems such as forests that had been cut down resulting in a lack of harvesting of bamboo and rattan.

Out of the total 102 respondents using bamboo and rattan products, 13 (12.7\%) depend on bamboo and rattan as their main source of income. Then 20 people (19.6\%) responded using it as a source of side income while most of them were 69 (67.6\%) respondents using bamboo and rattan products for their own use or consumption. Based on the findings, the lack of income from bamboo and rattan is due to the fact that more locals use bamboo and rattan products for their own use and as a side income. Based on the results, it is found that the majority of the population depend on bamboo and rattan as the source of income is $\mathrm{Kg}$ Kelawat which is 14 people followed by $\mathrm{Kg}$ Sumbilingon which is 10 people, Kg Pangi with 5 people and $\mathrm{Kg}$ Ponopuan which is 4 respondents. This is because $\mathrm{Kg}$. Kelawat and Kg Sumbilingon are close to the forest area while Kg Pangi have less forest resources whereas there are not many people involve in these activities in Kg Ponopuan because of the location is nearby to forest reserve.

$\mathrm{Kg}$ Pangi has the highest percentage of the total sales revenue of bamboo and rattan with a monthly income of $38.46 \%$ followed by Kg Sumbilingon of $35.77 \%$, Kg Kelawat by $31.34 \%$ and Kg Ponopuan by $20.51 \%$. The average percentage of total sales revenue of bamboo and rattan on a month's total income for all respondents was $31.85 \%$. This shows that even the involvement of locals on bamboo and rattan is high but when comes to products sales it only small because it is not their main source of income but only used for their own use. Revenue from sales of bamboo and rattan products can be categorized as low, as the population sells bamboo and rattan yields in small quantities and low prices. It also because there is not many locals who want to involve in the enterprise due to the lack of infrastructure.

Monthly income is derived from a total of 33 respondents who use bamboo and rattan as their source of income in the four fourth villages of which 13 are dependent on bamboo and rattan as the main income while 20 are for side income. Based on the results obtained, there were $3(9.1 \%)$ respondents receiving a revenue environment of RM800-RM999 for bamboo and rattan products followed by 4 
(12.1\%) respondents earning RM 500-RM799. Next, 9 (27.3\%) respondents earn RM 200-RM499 while the majority of respondents get less than RM200 for bamboo and rattan income in a month. The revenue from bamboo and rattan products is small because most of the bamboo and rattan products are used for their own use and are also used only as a sideincome.

Out of the 33 respondents who used bamboo and rattan as their source of income, it was found that $14(13.7 \%)$ of respondents sold handicrafts from bamboo and rattan for their socio-economic resources. Next, 10 (9.8\%) respondents sold bamboo and rattan as food sources for example bamboo shoots. In addition, bamboo and rattan products are also contributing in socioeconomics of $6(5.9 \%)$ respondents in manifucture furniture and there are $3(2.9 \%)$ respondents sell raw bamboo and rattan supplies to the wholesalers. Most of the sale of bamboo and rattan in handicraft and furniture was sold by traders in the Kota Belud town market to visitor every weekend. Raw rattan and bamboo collected are also sold to middlemen and wholesalers who involve in manifacturing products furniture and craft makers. Peter Dolmer (1997) interpreted the meaning of the craft as a skilled creative activity and the research of the processes that must be passed to produce woven art. As all known the talent of traditional people in Sabah in craft which become their hereditary tradition from older generation to preserve their culture. In addition, they also market bamboo and rattan products as a source of food such as bamboo shoots to sellers who sell along the Tamparuli main road. With the marketplace of these bamboo and rattan products, it facilitates the seller's business and also helps in increasing the livelihoods of local communities.

\section{Uses of Bamboo and Rattan Forest Products}

Bamboo and rattan is a non-timber forest product that has many uses and has commercial value for various products. The use of bamboo and rattan has long been associated with local communities in Malaysia (Wong, 1998). These bamboo and rattan are used by all races for the same purpose as meeting their needs. Based on the surveys conducted in the area of study, this plant grows much in the surrounding areas of the village and forest area. Therefore, the residents of these four villages still use bamboo and rattan product in their daily lives as well as the activities of collecting bamboo and rattan are still practiced and become the hereditary traditions. In addition beside their own uses, these bamboo and rattan products are also used as socioeconomic sources either as the main source of income and also the side income.

Based on the results obtained from the questionnaire of the villagers, 38 people (37.3\%) said the main uses of bamboo and rattan products are handicraft products. Various handicraft made of bamboo and rattan such as baskets, rag, basket, pen, ball, hood, fan, mat, tube and weaving tools. The indigenous native communities of Sabah are capable of producing a variety of interesting crafts from bamboo and rattan. Craft art has rules in its production. Craft practitioners are called craftsmen, in line with the skills inherited from heredity (Ismail Ibrahim, 2007). This handicraft production provides income sources at the same time helping to improve socio-economics as well as eradicating poverty and improving the standard of living of the community. In addition, Kota Belud area is a place famous for their handicraft production. The type of bamboo used to produce handicrafts is semantan, nipis, minyak, galah, beting and aur. 
A further study on 25 respondents (24.5\%) responded that the use of bamboo and rattan products was for furniture manufacturing. Furniture made of bamboo and rattan has a high demand in the community, this is because of its attractive and durable design besides its reasonable price. Among the furniture made of bamboo and rattan are chairs, tables, beds and closets. In addition, 19 (18.6\%) respondents agreed that the use of bamboo and rattan products as home construction. Bamboo is often used as a main component in the architecture of traditional houses in Sabah. Based on the area survey conducted there are still villagers who living in the interior of using bamboo in build their houses. In addition, they also use bamboo in the construction of 'sulap', a place such as cottage to store rice and also cage to store their livestock. Bamboo like semantan, minyak and beting are used as wall and floor of the house. In addition, bamboo is also widely used by villagers to be used as poles and fences to protect their residential and agricultural areas.

In addition, 17 (16.7\%) respondents chose the use of bamboo as a source of food. There is a part of a bamboo tree called bamboo shoots can be taken for food. Bamboo shoots is often taken and made as pickle to make delicious dishes. Besides bamboo, rattan can also be used as food source. The rattan is peeled and separated from the spines before the center inside it taken as a food. Then, it is boiled to reduce bitter taste. Lastly, the results shown $3(2.9 \%)$ respondents stated that bamboo and rattan can be used as another tool for example musical instruments. For example, musical instruments made by bamboo and rattan are flute, drum, angklung, keranting, and genggong. Usually old bamboo is selected and thin-walled bamboo types are used to make musical instruments.

\section{CONCLUSION}

From the studies conducted at the four villages in Kelawat, it can be concluded here that the two objectives of the study have been successfully achieved. This study has succeeded in meets the objective questions of studying the importance of bamboo and rattan forest products to the local community's socio-economic. It is found that villagers use bamboo and rattan forest products for their socioeconomic importance as the main source of income, side income and subsequent use of their own. These bamboo and rattan products are helping to improve their side income sources based on the amount of revenue they earn. A total of 73 out of 102 respondents also agreed and strongly agreed that bamboo and rattan were helpful in improving their socio-economic status. Indirectly here it is concluded that bamboo and rattan yields benefit in helping to improve the socio-economic of the local community.

The main uses of bamboo and rattan in result of surveys from all respondents first as a handicraft products, second being used as furniture manifucturing and house construction, then as a source of food and lastly as musical instruments. Bamboo and rattan is a non-wood forest product which has many uses and has commercial value that can be produced to various products. It has been used by the local community from their ancestral inheritannce to meet their own needs. In conclusion, based on the studies conducted, the uses and benefits of non-wood forest products bamboo and rattan to local communities can be identified. 
Community involvement on the use of bamboo and rattan as a source socioeconomics can provide social and economic benefits. In addition beside can improve living standards and also source of income, it also opens up employment opportunities to young people who want to engage in business, entrepreneurship and small enterprises as bamboo and rattan can afford giving a good rewards to people as a result of the awareness of uses and the advantages of this non-timber forest resource, especially in the manufacture of furniture, crafts, construction and so on.

For this country, the use of bamboo and rattan only need for commercial values and important exports to abroad. However, there is no doubt in rural area bamboo and rattan consumption is still use widespread in many aspects although there have been many different types of substances that can replace bamboo. Because of that, government should take this opportunity by providing infrastructure and enough technology to advance bamboo and rattan in various sectors. For example, with advice and guidance by providing knowledge of entrepreneurship courses to villagers to produce as well as diversifying handicrafts and furniture from bamboo and rattan. Besides opening up their interest in engaging in a small business it also helps in commercializing the handicraft industry produced by bamboo and rattan. Small and medium industries should seize the opportunities that available so that this industry can flourish further and improve country income.

In addition, continuous research on bamboo and rattan should be continued to ensure sustainable of resources other than improving the economy of this non-timber forest product. Study and research to ensure the durability of bamboo and rattan yields should be reviewed from time to time. Besides that, the way or the management of the stand should be done sustainably for ensuring the sustainability of non-timber forest products and rattan. Proper consumption on this non-timber forest resource is very important to avoid the lack of supply of this resource that leads to extinction.

\section{REFERENCES}

Abd Latif, M. \& Abd. Razak, O. (1998). Bamboo as an Alternative Planted and Industrial Material to Timber in Malaysia: Yield, Production and Utilization Points of View. San Jose, Costa Rica.

Mohmod, L. (2004).R\&D Needs Related to Bamboo and Rattan Small Enterprises. Forest Research Institute Malaysia (FRIM) Kepong 52109 Kuala Lumpur Malaysia.

Ahmed, A. (2007). Indigenous Use of Non Timber Forest Products in Kalash Valley Chitral. Pakistan Forest Department. Peshawar, Pakistan.

Brookfield, H.C., Potter, L. \& Byron, Y. (1995). In Place of the Forest: Environmental and Social Transformation in Borneo and Eastern Malay Peninsula. United Nations University Press, Tokyo.

Curran, D., \& M. M'Gonigle. (1999). Aboriginal Forestry: Community Management as Opportunity and Imperative. Osgoode Hall Law Journal 37(4): 711-774.

Dannenmann, B.M.E., Choocharoen, C., Spreer, W., Nagle, M., Leis, H., Neef, A. and Mueller, J. (2007). The potential of bamboo as a source of renewable energy in northern Laos. Conference on International Agricultural Research for Development, University of 
Kassel-Witzenhausen and University of Gottingen, October 9-11, 2007. Tropentag 2007.

Ibrahim, I. (2007). Warisan Motif dan Corak. Kota Kinabalu: Universiti Malaysia Sabah.

Dransfield, J. \& N. Manokaran eds. (1993). Plant resources of Southeast Asia - Rattans. PROSEA. Indonesia

Dolmer, P. (1997) .The Culture of Craft. Manchester: Manchester University Press.

Forestry Department, FAO Corporate Document Repository. (2007). Rattan: current research issues. Prospects for conservation and sustainable.

FAO. FAO Forestry. (1992). Towards a harmonised definition of non-wood forest products. Unasylva - No. 198, Vol. 50.

Ir. Baharudin, MP \& Ira Taskirawati. (2009). Hasil Hutan Bukan Kayu. Fakultas Kehutanan Universitas Hasanudin.

International Tropical Timber Organisation, (1997). Bamboo \& Rattan: Resources for the 21st Century. Tropical Forest Update. Vol.7. No.4.

Johari B., Salleh M.N, (2007). Sustainable Utilisation of Non Timber Forest Products. Issues and Prospects. Institute for Development Studies, Sabah, Malaysia.

Kashio, M., Durst, P.B., Ulrich, W., eds. (1994). Non-wood forest products in Asia. RAPA Publication 1994/28. FAO-RAPA., Bangkok.

Kanel, K. R. \& Dahal, G. R. (2008). Community Forestry Policy and Its Economic Implications: An Experience from Nepal.International Journal of Social Forestry, 2008, 1(1):50-60.

Kigomo, B. (2007). Guidelines for Growing Bamboo.Kenya Forestry Research Institute, KEFRI Pp 45.

Lacuna-Richman Celeste. (2007). Improving Commercial Possibilities of Non-wood Forest Products from Leyte the Philippines. Faculty of Forestry University of Joensuu, Finland

Marshall, E., Schreckenberg, K., Newton, A. (2003). Commercialization of non-timber forest products: First steps in analyzing the factors influencing success. Int Fores Rev, 2: 128137

Maxim L., Shyam P., Junqi Wu, Marco P. (2005). Non-Wood Forest Products 18 World Bamboo Resources. Framework of the Global Forest Resources Assessment 2005

Mirjam A.F. Ros-Tonen, K. Freerk Wiersum. (2003). The importance of non-timber forest products for forest-based rurallivelihoods: an evolving research agenda. Bonn, Germany

Murtedza, M. (1998). Sumber Alam. Kuala Lumpur: Dewan Bahasa dan Pustaka

Paglione, J.P.F. (2003). Sustainable biomass production utilizing bamboo. Alternative renewable non-wood resource.

Salkind, N. J. (1997). Exploring research (3rd Ed.). Upper Saddle River, NJ: Prentice Hall.

Salam, K. (2008). Bamboo for economic prosperity and ecological security with special reference tonorth-east India, CBTC, Guwahati. 
Scheer, S., White, A. and Kaimowitz, D. (2004). A new agenda for forest conservation and poverty reduction: Making markets work for low-income producers. Forest Trends, CIFOR, and IUCN. 160pp

Sunderland, T.C.H. \& Nkefor, J.P. (2000). The propagation and cultivation of African rattans. Paper presented at the international workshop African Rattans: A State of the Knowledge, Limbe, Cameroon, and 1-3 February.

Vermeulen, S. (2001). Memahami KF: Lima hal pokok yang perlu dipertimbangkan.Embarking on komuniti forestri: five points to keep in mind. IIED.

Wahab, R. (2006) Penanaman dan Pemprosesan dalam Pengurusan Buluh. Universiti Malaysia Sabah, Kota Kinabalu

WONG, W.E. (1988). Non-wood forest products - prospects for development. Proceedings of Workshops on Forest Sector Evaluat ion and Industrial Planning, p. 29-36, 3 -15 Oct. Serdang.

Corresponding Author: Wan Rafiekal Wan Abdul Rahim

Email: wanrafiekal@gmail.com 